\title{
Glycosylated haemoglobin and glucose intolerance in cystic fibrosis
}

\author{
P R STUTCHFIELD, S O'HALLORAN, J D TEALE, D ISHERWOOD, \\ C S SMITH, AND D HEAF \\ Departments of Child Health and Biochemistry, Royal Liverpool Children's Hospital, Alder Hey, Liverpool, \\ and the Department of Clinical Biochemistry, St Luke's Hospital, Guildford
}

SUMmaRY Sixty four patients, age range 1-20 years, with cystic fibrosis had their tolerance to glucose assessed according to their glycosylated haemoglobin $\left(\mathrm{HbA}_{1}\right)$ concentrations. Raised concentrations were found in $24(37 \cdot 5 \%)$. Oral glucose tolerance tests were performed on 21 patients with raised $\mathrm{HbA}_{1}$ and 13 patients with normal $\mathrm{HbA}_{1}$ concentrations. $\mathrm{C}$ peptide responses were also measured to assess islet cell function. Patients with normal $\mathrm{HbA}_{1}$ had normal glucose tolerance and $\mathrm{C}$ peptide response. Seven of 21 patients with raised $\mathrm{HbA}_{1}$ concentrations were glucose intolerant. The remaining 14 patients with raised $\mathrm{HbA}_{1}$ concentrations had normal glucose tolerance but a reduced $\mathrm{C}$ peptide response, suggesting impaired islet cell function. There were no appreciable differences in the incidence of chest infections, respiratory function, and chest $x$-ray scores among patients with normal $\mathrm{HbA}_{1}$ concentrations, raised $\mathrm{HbA}_{1}$ concentrations, and normal oral glucose tolerant tests, and patients who were glucose intolerant. No correlation was found between $\mathrm{HbA}_{1}$ concentration and age or Shwachman score. Measuring $\mathrm{HbA}_{1}$ concentrations periodically is useful in detecting and monitoring glucose intolerance in patients with cystic fibrosis.

The reported incidence of glucose intolerance in patients with cystic fibrosis ranges from $8-75 \%$. Insulin dependent diabetes occurs in $1-2 \%, 10$ times the incidence in the normal population. ${ }^{1}$ Glucose intolerance is thought to result from disruption of islet cells due to pancreatic fibrosis which progresses with increasing age and severity of the disease; consequently it is usually found only in older fibrocystic patients. Glucose intolerance may cause weight loss and may result in an increase in the incidence and severity of respiratory infections. Impaired neutrophil function has been described in the presence of high blood glucose concentrations, and a correlation has been shown between prevalence of infection among diabetics and the degree of glucose control..$^{2-5}$ We could find no such reports concerning patients with cystic fibrosis.

Poor glucose control results in glycosylation of haemoglobin with a corresponding increase in plasma concentrations. In insulin dependent diabetes concentrations of $\mathrm{HbA}_{\mathrm{lc}}$ correlate well with glucose control over the preceding 1-2 months. ${ }^{6}$ Caiger et al recently suggested that determining
$\mathrm{HbA}_{1}$ concentrations periodically may be useful in monitoring glucose intolerance in fibrocystic subjects. ${ }^{7}$ Raised $\mathrm{HbA}_{1}$ concentrations occur in such patients even when oral glucose tolerance tests give normal results. ${ }^{8}$

Islet cell function in fibrocystic patients has been investigated, usually by measuring insulin concenrations following a stimulation test. ${ }^{9-12} \mathrm{C}$ peptide is produced in equimolar proportions to insulin by cleavage of the pro insulin molecule in the $\beta$ cell of the pancreas; it has no primary biological activity. Its main role seems to be to maintain the configuration of the insulin molecule. Unlike insulin, C peptide is not degraded by the liver and measurement of its activity gives a reasonable assessment of islet cell function. ${ }^{13}$ The half life is $11-35$ minutes compared with that of insulin (4-3-9.8 minutes). For these reasons there is less variation in peripheral C peptide activity during oral glucose tolerance tests.

In this study we assessed the importance of raised concentrations of $\mathrm{HbA}_{1}$ in patients with cystic fibrosis by performing oral glucose tolerance tests and investigating islet cell function by measuring the 
$\mathrm{C}$ peptide response to the glucose challenge. We also examined the possible effects of glucose intolerance on cystic fibrosis.

\section{Patients and methods}

Sixty four patients, with an age range of 1-20 years, who attended the cystic fibrosis clinic at Alder Hey Children's Hospital from January to June 1985 were entered into the study. The ethical committee approved the study, and consent was obtained.

$\mathrm{HbA}_{1}$ and random blood glucose concentrations were estimated in all patients on entry into the study and repeated every two to six months. Patients with raised $\mathrm{HbA}_{1}$ concentrations, and where possible, age matched patients in whom $\mathrm{HbA}_{1}$ concentrations were normal, were admitted to the ward after an overnight fast for a standard oral glucose tolerance test. None of the patients was taking drugs that could influence glucose tolerance-for example, steroids or salbutamol-and none had acute infections at the time of the study. All had had an adequate intake of carbohydrate for at least three days before the glucose challenge. Glucose $(1.75$ $\mathrm{g} / \mathrm{kg}$, maximum $75 \mathrm{~g}$ ) was given orally with $100-300$ $\mathrm{ml}$ water. Blood was withdrawn through an intravenous cannula (which was maintained by an infusion of $0.9 \%$ saline) at 30 minute intervals from time 0 to 150 minutes for estimation of glucose concentrations and $\mathrm{C}$ peptide activity. Patients who were reluctant to be admitted for the oral glucose tolerance test were studied in the morning outpatient clinic. Blood from these patients was taken for estimation of glucose concentration at 0 and 120 minutes. The criteria used for the classification of the results of the glucose tolerance test depended on the fasting blood glucose concentration taken at these times. ${ }^{14}$

Glucose and $\mathrm{HbA}_{1}$ concentrations were estimated in blood preserved with fluoride oxalate. Samples were stored at minus $10^{\circ} \mathrm{C}$ for up to one week before analysis. Glucose was measured using a glucose oxidase method (Yellow Spring Instrument). $\mathrm{HbA}_{1}$ concentrations were determined by ion exchange column chromatography and spectrophotometry (Biorad haemoglobin $A_{1}$, by column test) and expressed as a percentage of the total haemoglobin. The interassay standard deviation for this method was 0.68 and the coefficient of variation $5.7 \%$. The reference range for our laboratory is $5 \cdot 3-8 \cdot 8 \%$ for $\mathrm{HbA}_{1}$, representing two SD limits of the mean in normal paediatric patients. A value of $\mathrm{HbA}_{1}$ above $9 \%$ was regarded as raised. The $\mathrm{C}$ peptide activity was measured by radioimmunoassay at St Lukes Hospital, Guildford. ${ }^{15}$ Heparinised blood was taken on ice and the serum separated and stored at $-200^{\circ} \mathrm{C}$ before analysis. Assay sensitivity has been calculated at $0.037 \mathrm{nmol} / \mathrm{l}$ with interassay variation of $0 \cdot 02-0 \cdot 1 \mathrm{nmol} / \mathrm{l}$.

The severity of each patient's disease was assessed using the Shwachman score,$^{16}$ pulmonary function tests, and chest $x$-ray score. Pulmonary function tests were performed regularly on all patients attending the clinic and included measurement of peak flow, forced vital capacity (FVC), and forced expiratory volume in one second $\left(\mathrm{FEV}_{1}\right)$. The chest $x$-rays were scored according to the Chrispin Norman scoring system. ${ }^{17}$

The incidence of severe chest infections over the past two years and the incidence of colonisation of the respiratory tract by Pseudomonas spp was determined from retrospective study of the case notes. A serious chest infection was defined as an episode resulting in an increase in cough or purulent sputum, or both, acute changes on the chest $x$-ray, and deterioration in pulmonary function necessitating admission to hospital.

Student's $t$ test was used to analyse the significance of differences between numbers, and the Mann-Whitney U test and Fisher's exact test for the differences between proportions.

\section{Results}

A raised $\mathrm{HbA}_{1}$ concentration (mean $10.6 \%$, range $9 \cdot 1 \%-17 \cdot 5 \%$ ) was found on entry into the study in 21 of the 64 patients attending the clinic, which indicated impairment of glucose control in $32.8 \%$. The mean (SD) $\mathrm{HbA}_{1}$ concentration of the remaining 43 patients was $7 \cdot 8(0 \cdot 9) \%$, range $5 \cdot 9-8 \cdot 8$. These results are comparable with those obtained from 21 normal children admitted to Alder Hey Children's Hospital for routine operations (mean (SD) $\mathrm{HbA}_{1}$ $7 \cdot 4(0.94) \%$, range $4 \cdot 6-8 \cdot 8)$. During the year after entry to the study, three more patients were found to have raised concentrations of $\mathrm{HbA}_{1}$.

Oral glucose tolerance tests were performed in 34 patients, each of whom had between two to six measurements of $\mathrm{HbA}_{1}$ in the year after entry to the study. These 34 patients included 21 of the 24 patients who had one or more raised $\mathrm{HbA}_{1}$ measurements, in addition to 13 other patients with cystic fibrosis of similar age who had normal concentrations of $\mathrm{HbA}_{1}$. The mean (SD) age of the two groups was $9 \cdot 2(5 \cdot 8)$ years and $10 \cdot 5(5 \cdot 1)$ years, respectively. Seven of the 21 patients $(33 \cdot 3 \%)$ with raised $\mathrm{HbA}_{1}$ concentrations had abnormal glucose tolerance test results; three produced a diabetic response and two of these were insulin dependent (Fig 1). All 13 patients with normal $\mathrm{HbA}_{1}$ concentrations had normal oral glucose tolerance test 
$\underline{H D A}_{1}$.

$\underline{\text { OGTT }}$

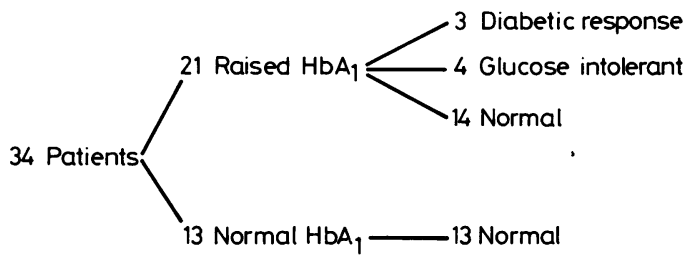

Fig. 1 Results of glycosylated haemoglobin and oral glucose tolerance tests in 34 patients with cystic fibrosis.

results. These differences are significant (Fisher's exact test, $\mathrm{p}<0.05$ ).

To investigate the importance of a raised $\mathrm{HbA}_{1}$ concentration and to examine islet cell function and the effects of glucose intolerance in more detail all the patients with cystic fibrosis were divided into three groups according to the result of the glucose tolerance test and the highest $\mathrm{HbA}_{1}$ concentration recorded during the previous year: group 1 normal subjects had $\mathrm{HbA}_{1}$ concentrations within the normal range and a normal oral glucose tolerance test; group 2 had a raised serum $\mathrm{HbA}_{1}$ concentration and a normal oral glucose tolerance test result; and group 3 had a raised concentration of $\mathrm{HbA}_{1}$ and an abnormal oral glucose tolerance test result.

The mean (SD) age of patients in group $1(n=13)$ was $10 \cdot 5(5)$ years (range $3-19 \cdot 8)$, in group $2(n=14)$ $7(4 \cdot 7)$ years (range $2 \cdot 3-15 \cdot 8)$, and in group $3(n=7)$ $13 \cdot 6(5 \cdot 7)$ years (range $3 \cdot 8-19 \cdot 5)$. The Table shows the mean fasting concentrations of glucose values at the time of the oral glucose tolerance test; the differences between these groups were not significant. There was, however, a significant difference between the mean $\mathrm{HbA}_{1}$ concentrations at the time of the oral glucose tolerance test in both group 2 $(\mathrm{p}<0.05)$ and group $3(\mathrm{p}<0.01)$ when compared with the normal group (Table). Blood for estimation of $\mathrm{HbA}_{1}$ concentration was taken at time zero.

Table Mean (SD) fasting blood glucose concentrations and $\%$ glycosylated haemoglobin in 34 patients with cystic fibrosis

\begin{tabular}{lll}
\hline & $\begin{array}{l}\text { Fasting blood } \\
\text { glucose concentration } \\
(\text { mmolll) }\end{array}$ & $\begin{array}{l}\% \text { Glycosvlated } \\
\text { haemoglobin }\end{array}$ \\
\hline $\begin{array}{l}\text { Normal subjects }(\mathrm{n}=13) \\
\begin{array}{l}\text { Patients with raised } \\
\text { concentration of } \\
\text { glycosylated }\end{array}\end{array}$ & $4.2(0 \cdot 4)$ & $7.2(0 \cdot 8)$ \\
$\begin{array}{l}\text { haemoglobin }(\mathrm{n}=14) \\
\text { Patients with glucose } \\
\text { intolerance }(\mathrm{n}=7)\end{array}$ & $3.9(0 \cdot 5)$ & $8.8(1 \cdot 3)$ \\
\hline
\end{tabular}

Detailed analysis of the response of the islet cells to the glucose tolerance test was only possible in 24 of the 34 patients. The 10 patients not included completed the test in the clinic, having blood taken at time 0 and 120 minutes only. Figure 2 shows the number of patients in each group completing the full test. This graph shows the mean (SE) glucose concentration at each sampling time for each group during the oral glucose tolerance test. Patients in groups 1 and 2 produced similar glucose profiles, but the mean peak glucose concentration was reached at 30 minutes in group 1 and at 60 minutes in group 2 . There were similar glucose concentrations at 120 minutes $(5.6 \mathrm{mmol} / \mathrm{l}$ and $5.3 \mathrm{mmol} / \mathrm{l}$, respectively). The peak mean glucose concentration of patients in group 3 was reached at 90 minutes with a mean glucose concentration of $11.7 \mathrm{mmol} / \mathrm{l}$ at 120 minutes.

Figure 3 shows the mean $\mathrm{C}$ peptide activity at each sampling time for each of the groups of

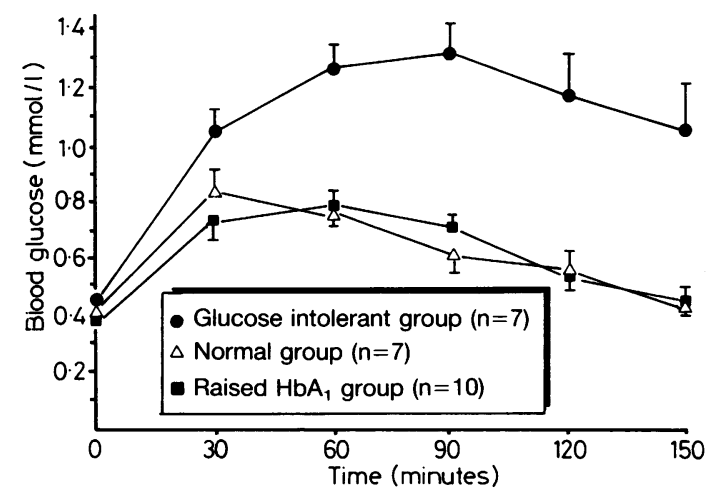

Fig. 2 Mean (SEM) glucose concentrations during oral glucose tolerance tests in 24 patients with cystic fibrosis.

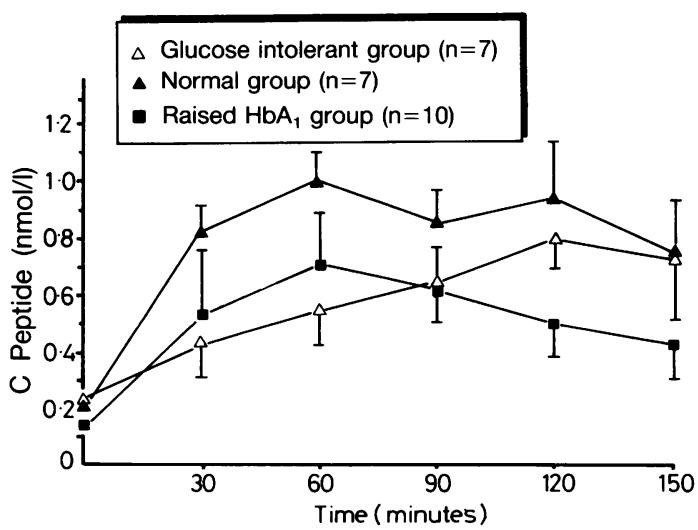

Fig. 3 Mean (SEM) C peptide concentrations during oral glucose tolerance tests in 24 patients with cystic fibrosis. 
patients. There was a rapid increase in $\mathrm{C}$ peptide activity in patients in the normal group to a peak at 60 minutes followed by a gradual fall. A slow rise, also with a peak at 60 minutes, was seen in group 2, but lower concentrations were present at all times. The rise in $\mathrm{C}$ peptide activity in group 3 was delayed, with a peak at 120 minutes; only two of the seven patients produced peak concentrations before 120 minutes (at 60 and 90 minutes). In the first two groups 11 of 17 had peak values at or before 60 minutes. Significant differences $(\mathrm{p}<0.05)$ were seen between measurements of $C$ peptide activity at 30 and 60 minutes between groups 1 and 3 in addition to that between groups 1 and 2 at 120 minutes $(\mathrm{p}<0 \cdot 05)$.

Two girls, aged 17 and 19 required insulin for symptomatic glucose intolerance; this was started two and four years before the study. Doses of insulin of 0.8 and 1.3 units $\mathrm{kg} / 24$ hours, respectively, were needed to achieve adequate control. On the day of the oral glucose tolerance test the morning dose of insulin was omitted following the overnight fast. Fasting glucose concentrations of 5.0 and $3.0 \mathrm{mmol} / \mathrm{l}$ were obtained. Maximum recorded $\mathrm{C}$ peptide activity occurred at 120 minutes in both, with values of $1 \cdot 1 \mathrm{nmol} / \mathrm{l}$ and $0.3 \mathrm{nmol} / \mathrm{l}$ respectively. Neither had episodes of hyperglycaemic ketoacidosis.

The peak $\mathrm{HbA}_{1}$ concentration for each of the 34 patients recorded during the year of the study correlated significantly with the $\mathrm{HbA}_{1}$ concentration measured in blood taken at the time of the oral glucose tolerance test $(r=0.47 p<0.05)$. There was a negative correlation between $\mathrm{HbA}_{1}$ concentrations and total $\mathrm{C}$ peptide activity, but this did not reach significance.

Patients with glucose intolerance were not significantly different from the normal group in respect of Shwachman score, number of serious chest infections, colonisation with Pseudomonas spp, lung function, and chest $x$-ray scores. The body mass index and height for age of patients among the groups did not differ significantly.

\section{Discussion}

When patients with cystic fibrosis attending Alder Hey Children's Hospital were screened for evidence of glucose intolerance, 24 of $64(37.5 \%)$ were found to have raised $\mathrm{HbA}_{1}$ concentrations. Glucose intolerance indicated by a standard oral glucose tolerance test was found in $33 \%$ of the patients assessed who had one or more raised measurements of $\mathrm{HbA}_{1}$ concentration. All the patients who had consistently normal $\mathrm{HbA}_{1}$ concentrations also had normal glucose tolerance. Dividing the patients into three groups enabled more detailed comparison to be made of the islet cell function as assessed by the blood glucose concentrations and $\mathrm{C}$ peptide activity during the oral glucose tolerance test.

The glucose profiles obtained from concentrations in blood measured during the oral glucose tolerance test groups 1 and 2 were similar, with comparable glucose concentrations recorded at 120 minutes. Differences were found in the islet cell response to the oral glucose load, however, when measurements of the $C$ peptide activity were compared. Group 2 produced a slower rise in $\mathrm{C}$ peptide activity following the glucose load, with lower $C$ peptide activity recorded at all times. This indicated impaired $\beta$ cell reserve in patients with raised $\mathrm{HbA}_{1}$ concentrations alone.

Peak glucose concentrations were reached at 30 minutes in group 1 and at 60 minutes in group 2, with peak $C$ peptide activity in both groups at 60 minutes. In a normal population peak glucose concentrations occur at 30 minutes $^{9} 1819$ and peak C peptide activity between 30 and 60 minutes ${ }^{18-20}$ after an oral glucose load.

The mean (SD) rise in $\mathrm{C}$ peptide activity was 1.01 $(0 \cdot 2) \mathrm{nmol} / \mathrm{l}$ in the group of patients who had normal $\mathrm{HbA}_{1}$ concentrations and normal glucose tolerance. This compares with the range of mean values $(0 \cdot 9-2 \cdot 2 \mathrm{nmol} / \mathrm{l})$ recorded in normal adults. ${ }^{18-20}$ Low immunoreactive insulin responses to glucose loads have been reported in patients with cystic fibrosis. ${ }^{9}{ }^{10}$ By simultaneously measuring $\mathrm{C}$ peptide activity and insulin concentrations, Mohan et al showed that lower insulin concentrations in patients with cystic fibrosis are likely to be due to pancreatic $\beta$ cell hypofunction rather than increased degradation of insulin in the liver. ${ }^{21}$ Increased responsiveness to insulin in peripheral tissue has been suggested as a cause in patients with cystic fibrosis, ${ }^{10}$ with an increase in the number and affinity of insulin receptors. ${ }^{22}$ The data, are however, conflicting. ${ }^{11}$

The glucose intolerant patients showed peak C peptide activity at 120 minutes, indicating defective release of insulin. These results agree with those obtained by Handwerger et al. ${ }^{9}$ The two insulin dependent patients studied both produced peak $\mathrm{C}$ peptide activity at 120 minutes. The patient who had been insulin dependent for two years, requiring insulin $0 \cdot 8$ units $/ \mathrm{kg} / 24$ hours, produced a peak C peptide activity of $1.1 \mathrm{nmol} / \mathrm{l}$. The other, an older patient who had been insulin dependent for four years and needed 1.3 units $/ \mathrm{kg} / 24$ hours, produced a delayed poor response with peak activity of only $0 \cdot 3$ $\mathrm{nmol} / \mathrm{l}$, possibly indicating progressive deterioration in $\beta$ cell function. Neither had episodes of ketoacidosis, and there was no family history of diabetes in either patient. Although the insulin requirements in patients with cystic fibrosis who develop diabetes 
are high $(0 \cdot 6-3 \cdot 3$ units $/ \mathrm{kg} /$ day $),{ }^{1}$ episodes of ketoacidosis do not occur. This has been explained by a reduced dietary fat intake in these patients, and the inability of the pancreas to produce sufficient glucagon. Glucagon directly opposes the action of insulin producing glycogenolysis, gluconeogenesis, and lipolysis. In diabetic patients with relatively severe diabetic ketoacidosis absolute hyperglucagonaemia has been reported. ${ }^{23}$ Impaired glucagon production has been shown in patients with cystic fibrosis. ${ }^{11}$

We found a significant correlation between fasting and peak $C$ peptide activity. This has also been shown in diabetic patients ${ }^{24}$ and indicates that the production of $\mathrm{C}$ peptide follows the law of the initial value, which states that the magnitude of the response is related to the concentration before stimulation. ${ }^{25}$ Fasting $C$ peptide activity recorded in the three groups did not, however, differ significantly. There were also no significant differences in the increase and peak of $C$ peptide activity achieved.

The highest recorded $\mathrm{HbA}_{1}$ concentration for each patient obtained during the study year correlated significantly with the $\mathrm{HbA}_{1}$ concentration measured at time zero during the oral glucose tolerance test, indicating a persistent increase in $\mathrm{HbA}_{1}$ concentrations. A negative correlation was found between the $\mathrm{HbA}_{1}$ concentration recorded at the time of the oral glucose tolerance test and the sum of $C$ peptide activity. Although this did not reach significance, Bistritzer et al ${ }^{12}$ found a significant negative correlation between the sum of the insulin concentrations during the oral glucose tolerance test and the $\mathrm{HbA}_{1}$ concentration in 11 patients with cystic fibrosis. This suggests that the lower the insulin response to a glucose challenge, the higher the $\mathrm{HbA}_{1}$ concentration.

The commercial method (Biorad) used in this study estimates total glycosylated haemoglobin. No attempt was made to remove the labile fraction, which has been shown to correlate with the glucose concentration at the time of sampling. ${ }^{26}$ To reduce this complicating factor blood for $\mathrm{HbA}_{1}$ assay was taken at time zero during the oral glucose tolerance test. No significant differences in the fasting glucose concentrations were found between the groups. We have shown that $\mathrm{HbA}_{1}$ concentration is useful in assessing glucose tolerance in patients with cystic fibrosis. High concentrations of $\mathrm{HbA}_{1}$ indicate impaired $\beta$ cell reserve with decreased or delayed insulin release.

There was no correlation between raised $\mathrm{HbA}_{1}$ and age, as found by Bistritzer et al. ${ }^{12}$ For this reason all patients with cystic fibrosis should be assessed periodically for glucose intolerance. High concentrations of fetal haemoglobin in newborns and in some 1-2 year olds may produce falsely raised $\mathrm{HbA}_{1}$ concentrations because fetal haemoglobin elutes with $\mathrm{HbA}_{1}$ as a fast band on ion exchange column chromatography. Alternative methods of measuring $\mathrm{HbA}_{1}$ that eliminate this error should be used in patients below the age of 2 years. The youngest glucose intolerant patient in our study was 3 years 8 months old. $\mathrm{He}$ had a $\mathrm{HbA}_{1}$ concentration of $10.3 \%$ and blood glucose at 120 minutes of $9 \cdot 3$ $\mathrm{mmol} / \mathrm{l}$. He did not have glycosuria and was asymptomatic. His progress is being followed closely.

The clinical course of insulin dependent diabetes mellitus in cystic fibrosis is mild. Ketoacidosis does not occur and complications are rare. Provided growth is adequate and the patient is not troubled by symptomatic hyperglycaemia, the motivation to achieve good control is poor. The effect of glucose intolerance on infection in patients with cystic fibrosis has not been investigated.

Rayfield $e t$ al found a striking correlation between the overall prevalence of infection and mean plasma glucose concentrations in insulin dependent diabetes. ${ }^{5}$ In vitro studies have shown impairment of opsonisation, ${ }^{4}$ neutrophil adherence, ${ }^{2}$ chemotaxis, ${ }^{3}$ phagocytosis, ${ }^{4}$ and bactericidal activity ${ }^{5}$ in the presence of hyperglycaemia. Glucose intolerance may lead to an increase in the prevalence and severity of respiratory infections in patients with cystic fibrosis. In this study, however, no significant differences were found in the number of chest infections, the prevalence of colonisation with Pseudonomas spp, respiratory function, or the Shwachman score in the patients with cystic fibrosis and glucose intolerance compared with those with normal glucose intolerance.

In conclusion, periodic assessment of $\mathrm{HbA}_{1}$ concentration is useful in determining the presence of glucose intolerance in patients with cystic fibrosis and in monitoring its course. Evidence of impaired $\beta$ cell reserve was found in patients with raised $\mathrm{HbA}_{1}$ concentrations, $33 \%$ of whom were glucose intolerant during an oral glucose tolerance test. Impaired neutrophil function as a result of hyperglycaemia may lead to an increase in the number and severity of chest infections. We did not, however, show such an effect in this study, and further in vitro and in vivo studies are necessary to investigate this.

We thank Mrs D Bolger for preparing this paper.

\section{References}

1 Green OC. Endocrinological complications associated with cystic fibrosis. In Lloyd Still JD, eds. Textbook of cystic fibrosis. 1st ed. Bristol: John Wright 1983;329-50.

2 Bagdade JD. Stewart M. Walters E. Impaired granulocyte adherence: a reversible defect in patients with poorly controlled diabetes. Diabetes 1978:27:677-81. 
${ }^{3}$ Miller ME. Baker L. Leucocyte function in juvenile diabetes mellitus: humoral and cellular aspects. $J$ Pediatr 1972;81:979-82.

4 Davidson NJ, Sowden JM, Fletcher J. Defective phagocytosis in insulin controlled diabetes: evidence for a reaction between glucose and opsonising proteins. J Clin Pathol 1984:37:783-6.

5 Rayfield EJ, Ault MJ. Keusch GT. Brothers MJ, Nechemias C, Smith H. Infection and diabetes; the case for glucose control. Am J Med 1982;72:439-49.

6 Mayer TK, Freedman ZR. Protein glycosylation in diabetes mellitus: a review of laboratory measurements and of their clinical utility. Clin Chim Acta 1983;127:147-84.

7 Caiger P, Frost GJ, Bruce LE. Wilson SGF. Cystic fibrosis and diabetes mellitus. Arch Dis Child 1987;62:101-2.

${ }^{\star}$ Paulsen EP, Koury M. Hemoglobin $\mathrm{Al}_{\mathrm{c}}$ levels in Insulindependent and -independent diabetes mellitus. Diabetes 1976;25:890-6.

${ }^{9}$ Handwerger S, Roth J, Gordon P, Di Sant'Agnese P, Carpenter DF, Peter G. Glucose intolerance in cystic fibrosis. $N$ Engl J Med 1969;281:451-61

11) Wilmshurst EG, Soeldner JS. Holsclaw DS, et al. Endogenous and exogenous insulin responses in patients with cystic fibrosis. Pediatrics 1975;55:75-82.

11 Lippe BM, Sperling A, Dooley RR. Pancreatic alpha and beta cell functions in cystic fibrosis. J Pediatr 1977;90:751-5.

12 Bistritzer T, Sack J, Eshkol A, Katznelson D. Haemoglobin A, and pancreatic beta cell function in cystic fibrosis. Isr J Med Sci 1983;19:600-3.

13 Hoekstra JBL, Van Rijn HJM, Erkelens DM. Thijssen JHH. C peptide-a review. Diabetes Care 1982;5:438-46.

14 Teuscher A, Jarrett RJ. Diabetes mellitus: diagnostic criteria. Diabetic Medicine 1984;1:305-7.

15 Hampton S. The C peptide of pro-insulin: its diagnostic use and a possible physiological role. Guildford: University of Surrey, 1983. (PhD thesis).

16 Shwachman H, Kulczycki LL. Longterm study of one hundred five patients with cystic fibrosis. Am J Dis Child 1958:96:6-15.
17 Chrispin AR, Norman AP. The systematic evaluation of the chest radiograph in cystic fibrosis. Pediatr Radiol 1974;2:101-6.

18 Small M, Cohen HM. Beastall GH. MacCuish AC. Comparison of oral glucose loading and intravenous glucagon injection as stimuli to $\mathrm{C}$ peptide secretion in normal men. Diabetic Medicine 1985:2:181-3.

19 Heding LG, Rasmussen SM. Human C peptide in normal and diabetic subjects. Diabetologia 1975;11:201-6.

${ }^{20}$ Block MB, Mako ME, Steiner DF, Rubenstein AH. Circulating $C$ peptide immunoreactivity. Studies in normal and diabetic patients. Diabetes 1972;21:1013-26.

21 Mohan V, Alagappan V. Snehalatha C, Ramachandran A, Thiruvengadam KV, Viswanathan $\mathrm{M}$. Insulin and $\mathrm{C}$ peptide responses to glucose load in cystic fibrosis. Diabete Metab 1985:11:376-9.

22 Lippe BM, Kaplan SA, Neufeld ND. Smith A, Scott M. Insulin receptors in cystic fibrosis: increased receptor number and altered affinity. Pediatrics 1980;65:1018-22.

23 Muller WA, Faloona GR. Unger RH. Hyperglucagonaemia in diabetic ketoacidosis. Its prevalence and significance. Am J Med 1973:54:52-7.

${ }^{24}$ Faber OK, Binder C, Klampenborg MD. C peptide response to glucagon: A test for the residual beta cell function in diabetes mellitus. Diabetes 1977;26:605-10.

25 Bicrman EL. Law of the initial value. Lancet 1976;i:1076-7.

${ }^{26}$ Goldstein DE, Peth SB, England JD, Hess RL, Da Costa J. Effects of acute changes in blood glucose in $\mathrm{HbA}_{1}$. Diabetes 1980;29:623-8.

Correspondence to $\mathrm{Dr}$ P R Stutchfield, Department of Child Health, Royal Liverpool Children's Hospital (Alder Hey). Eaton Road, Liverpool L12 2AP.

Received 9 April 1987 